\title{
Chapter 14 \\ American Classified Paper of 1988 \\ and the Case of Nagorno-Karabakh \\ Conflict
}

\author{
Michael Lambert
}

\subsection{Background}

In 1988, the US Central Intelligence Agency (CIA) declassified a research paper with the title, "Unrest in the Caucasus and the challenge of Nationalism" on the Nagorno-Karabakh autonomous oblast time when the conflict between Armenia and Azerbaijan was emerging. It lasted until 1994.

The 44-page document from 1988 provided insights into the US intelligence knowledge of this region at the heart of Armenian-Azeri tensions. Over 30 years ago, the paper underlined the difficulties for the Soviet leaders to keep the status quo of peace and stability established during the Soviet period. This strategic intelligence paper from 1988 is an important piece of the puzzle in understanding contemporary politics and peace-building in the Caucasus. It highlights the ethnic and religious tensions that existed across the Soviet Union and continue to be one of the main reasons for outbreaks of violence.

Therefore, it is instructive to look back to the 1980s and the strategic choices made at that time by the United States and the USSR to understand the current context in the region.

The Nagorno-Karabakh war of 2020 highlighted the growing disparities between Armenia and Azerbaijan in the post-Soviet order, resulting in a modern Azerbaijan capable of conducting advanced military operations while Armenia relied on Soviet equipment. Moreover, Azerbaijan had a strategic advantage over Armenia and Nagorno-Karabakh, due to the support by other emerging powers in the region, such as Turkey.

Since the collapse of the USSR, Baku has managed to develop its economy through the sale of oil and gas on the international market and develop partnerships with countries such as Israel, a supplier of unmanned aerial vehicles (UAVs), into action

M. Lambert ( $\square)$

OSCE Academy in Bishkek, 30 rue Croix fontaine, 77240 Seine-Port, France

e-mail: michael.lambert@insead.edu 
during the conflict in 2020. On 9 November 2020, the Azeri attack on a Russian Mi-24 helicopter on Armenian territory prompted Moscow to provide some peacekeepers, in total 1,960 soldiers and 90 armoured personnel carriers. The aim is to remain for at least 5 years, which reverses earlier Russian government decisions not to send soldiers during and after the 1988 to1994 war between these two countries.

The 2020 pro-active approach by Moscow changes the dynamics in NagornoKarabakh. That this would happen was already mentioned by the CIA in $1988 .{ }^{1}$ Nevertheless, and contrary to the Soviet era, in 2020, the Russian government could have an economic advantage in intervening in the region because it will push both countries to purchase more Russian equipment in an attempt to develop relations with Moscow. Furthermore, it confirms Russia's return as a major power on the international scene and changes relations within the OSCE. As such, Russia is now the only co-chair in the Minsk Group to have troops in Nagorno-Karabakh, unlike other members, such as France and the United States. Thirty years after the collapse of the USSR, the US administration does not officially recognise Nagorno-Karabakh as a territory independent from Azerbaijan. There are nevertheless nine American states, namely California (2014), Georgia (2016), Hawaii (2016), Louisiana (2013), Maine (2013), Massachusetts (2012), Michigan (2017), Rhode Island (2012) and Colorado (2019) that passed separate bills on the state level recognising the "Republic of Artsakh," another name given to Nagorno-Karabakh as an independent country on the basis of the Montevideo Convention. ${ }^{2}$ This discrepancy between the diplomatic position of the US administration versus its federal states has already been highlighted in the 1988 CIA research paper and helps to understand contemporary American diplomacy with regard to Nagorno-Karabakh.

The events of 27 September to 10 October 2020 have changed the dynamic between Baku and Yerevan in Nagorno-Karabakh with the return of certain occupied territories to the control of Azerbaijan. Russian peacekeepers are also developing an option presented already by the CIA in 1988. The CIA already had documents, namely the "Who's Who-Political, Military," 1949, that was declassified in 2011, and the "Indication of Psychological Vulnerabilities," 1952, declassified in 2003, and the "History of Animosity between Armenians and Azeris," 1988, declassified in 2012, as well as "Unrest in the Caucasus and the Challenge of Nationalists," 1988, declassified in 1999, published in order to understand what the CIA knew and how this continues to influence the US Department of State's policy in international organisations, including the OSCE.

\footnotetext{
${ }^{1}$ Central Intelligence Agency (1988) Unrest in the Caucasus and the Challenge of Nationalist (declassified in 1999) https://www.cia.gov/readingroom/docs/CIA-RDP91B00776R000600 150001-9.pdf

2 This recognition was supported by members of the Democratic Party in each of the U.S. states mentioned above, without any evidence of a common strategy within the Democratic Party.
} 


\subsection{Territorial Conflict Over Nagorno-Karabakh and US Position}

A policy brief written by William Webster $^{3}$ for the American Vice President dating back to 16 June $1988^{4}$ on the "History of Armenian-Azeri Animosity" attempts to explain the reasons for the conflict between Armenians and Azeris over control of the region. According to the document, the ethnic and religious differences between Azeris, that are an ethnic group of Turkic origin, mainly following Shiite Islam, and Armenians, followers of Orthodox Christianity and the Armenian Church, have always existed but with even greater intensity in Nagorno-Karabakh. Armenia and Azerbaijan became two independent states after World War I from 1917 to 1920. But the animosity, which was also related to ethnicity and religion, culminating in the Armenian Genocide during WWI in 1915 by the Turkish Sultanate, played into the favour of the Red Army. The Soviet government took advantage of this division to increase its hegemony and integrate both countries into the Soviet Union.

In 1920, the Bolsheviks wished to incorporate Karabakh into the Azerbaijan Soviet Socialist Republic of Azerbaijan (Azerbaijan SSR), before deciding in favour of the Armenian Soviet Socialist Republic (Armenian SSR) on the basis of the ethnic composition of Karabakh. According to the CIA, ${ }^{5}$ the decision to incorporate Nagorno-Karabakh, a predominantly ethnic Armenian territory, into Azerbaijan is linked to the apprehension of Turkish leaders who did not wish to witness the birth of a Greater Armenia. ${ }^{6}$ Moscow's choice to separate Karabakh from Armenia by turning it into the Autonomous Oblast of Nagorno-Karabakh in 1923 would therefore be the result of Turkish influence in the USSR rather than a Stalinist policy aimed at bringing together antagonistic groups. At that time, Webster's brief to the American vice-president did not fail to add to the apprehension of the inhabitants of the South Caucasus. Despite Moscow's choice to attach Karabakh to Azerbaijan instead of Armenia, the Azeris consider that Moscow nevertheless exercises a form of favouritism towards the Armenians because the latter are Orthodox Christians like most of the Russian elite.

\subsection{Multi-Lateral Favouritism in the Region}

In addition to territorial conflicts, the 1988 CIA paper, "Unrest in the Caucasus and the Challenge of Nationalism," mentions the faster population growth of the

\footnotetext{
${ }^{3}$ Ronald Reagan chose him to be Director of the CIA from 1987 to 1991.

${ }^{4}$ Declassified in 2012.

${ }^{5}$ Central Intelligence Agency (1988) Unrest in the Caucasus and the Challenge of Nationalist (declassified in 1999) https://www.cia.gov/readingroom/docs/CIA-RDP91B00776R000600 150001-9.pdf.

${ }^{6}$ A Greater Armenia might lead to more territorial claims, including former Armenian territories located in post-First World War Turkey.
} 
Azerbaijani SSR compared to the Armenian SSR. That would, according to the authors, make it difficult for young Azerbaijanis to find adequate employment and housing in an economically troubled USSR in the 1980s. The USSR has not been able to invest in new infrastructure for young people in Azerbaijan, and this would increase resentment towards Armenians who enjoy a better quality of life. It further states, that the "Economic dissatisfactions further aggravated by dramatic population growth particularly in the age group seeking employment. In the last decade Azerbaijan has experienced a youth bulge ( 20 percent or more of the population in the 15-24 years old age group) which could not be easily absorbed. This problem was compounded by the general lack of labour minority. Azeri youth, even when well trained, showed little inclination to move to labour short Slavic regions. According to Soviet media, there are 250,000 people in Azerbaijan who are 'not employed in social production' one-fourth of these live in the city of Baku." Central Intelligence Agency (CIA), Unrest in the Caucasus and the Challenge of Nationalist, 1988 and declassified in 1999. ${ }^{7}$

In order to reduce tensions between Armenians and Azeris and to maintain the status quo in the South Caucasus, conservative Soviet leaders, including Ligachev and KGB Director Chebrikov, adopted a strict line to restore order with the intelligence services and a constant military presence, which is fuelling the debate on the future of Nagorno-Karabakh in Azerbaijan in 1988. ${ }^{8}$

The CIA report mentions the beginning of discussions between Azeris and Armenians in Moscow, and the possibility of bringing the whole of Nagorno-Karabakh under direct Moscow control instead of giving it to one side or the other. This would have been a solution that would not satisfy either Azeris or Armenians, but could have avoided the outbreak of a conflict, according to the authors. It all came to be evident, when, in 2020, the arrival of the Russian peacekeeping forces was not welcome to the Armenians even though the latter were losing the whole of Nagorno-Karabakh. Russian military intervention came at a time when Baku had regained control of the emblematic city of Susha/Sishi. And in accordance with the agreements signed on November 9, 2020, a large part of the territories occupied by the Armenians will return to Azerbaijan's control, which therefore amounts to a territorial loss without fighting.

\subsection{The Role of the Armenian Diaspora in the US}

Back in 1988 the CIA paper portrays glasnost and perestroika as an attempt to satisfy the Russian people's growing need for freedom in the USSR. However, the

\footnotetext{
${ }^{7}$ Central Intelligence Agency (1988) Unrest in the Caucasus and the Challenge of Nationalist (declassified in 1999) https://www.cia.gov/readingroom/docs/CIA-RDP91B00776R000600 150001-9.pdf.

${ }^{8}$ Central Intelligence Agency (1988) Unrest in the Caucasus and the Challenge of Nationalist (declassified in 1999) https://www.cia.gov/readingroom/docs/CIA-RDP91B00776R000600 150001-9.pdf.
} 
same report points out that this freedom of expression could have unintended consequences for non-Russian ethnic groups such as Armenians and Azeris. While Soviet leaders attribute the sudden rise in violence and nationalism in Nagorno-Karabakh to foreign influence, the CIA has also noted the laissez-faire attitude of local actors such as Azeri and Armenian police who provided assistance to people of the same ethnic background. In October 1987, for example, a rally in the Armenian capital of Yerevan in Opera Square for the "Return of Artsakh" to the Armenian SSR underlined the growing tensions over Nagorno-Karabakh's membership, and the resurgence of identity tensions in the context of glasnost. And later, in February 1988, a vote was held in the Autonomous Oblast of Nagorno-Karabakh, which resulted in a majority in favour of a transfer from the Azerbaijani SSR to the Armenian SSR. A month later, in March 1988, the former head of the Russian State and leader of the communist party, Mikhail Gorbachev, received in Moscow the Armenian and Azeri representatives Karen Demirchyan and Kamran Baghirov to discuss Nagorno-Karabakh and its future. ${ }^{9}$

The then classified CIA report was drawn up in this context, aware of the possibility of Moscow's military intervention in an ethnically troubled Soviet Caucasus, which could have consequences for stability on the border with Turkey-a NATO member and US ally. The US intelligence agency compared the context of the Soviet Autonomous Oblast of Nagorno-Karabakh with what was happening in the Abkhazia SSR. In contrast to the Abkhazia SSR, relations between the Azerbaijan SSR and Turkey suggest that Turkey might support Baku (Azerbaijan SSR) in the NagornoKarabakh conflict lead to the first post-cold war between USSR and NATO in the Caucasus. Consequently, the CIA had a direct interest in focusing its attention on this part of the USSR - unlike the Soviet Baltic states which soon became independent states and later joined the European Union-in order to avoid a direct conflict between Turkey and the newly established Russian Federation. During the war of 2020, Turkey, to no surprise, adopted a pro-Azeri attitude and Western allies like France criticised this choice, which led to further degraded relations between Paris and Ankara that had already existed due to French anti-terrorism policies in respect to Islamist groups.

Not surprisingly, the Armenian Diaspora around the world in Russia, France and the US, with an estimate of between 500,000 and 800,000 in the US alone, became nervous. The CIA analysis mentions elements to be taken into account and directly related to political stability in the United States, including the influence of the Armenian diaspora in California, above all. ${ }^{10}$ According to the report, members

\footnotetext{
${ }^{9}$ Central Intelligence Agency (1988) Unrest in the Caucasus and the Challenge of Nationalist (declassified in 1999) https://www.cia.gov/readingroom/docs/CIA-RDP91B00776R000600 150001-9.pdf.

10 The first major wave of Armenian immigration to America took place in the late nineteenth and early twentieth centuries. Thousands of Armenians settled in the United States - mostly in California - following the Hamidian massacres of the mid-1890s, the Adana Massacre of 1909, and the massacres of 1915 in the Ottoman Empire. Since the 1950s many Armenians from the Middle East migrated to America as a result of political instability in the Middle East. It accelerated in the late 1980s and has continued after the collapse of the USSR in 1991. Armenians have an emotional
} 
of the Armenian diaspora could have an influence on the position of certain American states on the diplomatic line to adopt regarding Nagorno-Karabakh. US citizens of Armenian origin could interfere with relations between Washington and Ankara if Washington, and above all the Democratic Party, decided to assume a pro-Armenian diplomatic position to satisfy voters of Armenian origin in the two American federal states which later recognised Nagorno-Karabakh as independent. Consequently, the two NATO members US and Turkey disagree on the support to be given to NagornoKarabakh. Consequently, the CIA report anticipated the conflict within the USSR in the late 1980s and its repercussions on relations within NATO. Turkey is also presented as a power that does not wish to become involved in the Nagorno-Karabakh conflict. Turkey supported and has continued to do so also in 2020, Azerbaijan. In the CIA report it was stated that "Turkey no doubt especially feared that transferring Nagorno-Karabakh to Armenia would whet Armenian appetites and lead to increased pressure to change the status of Nakhichevan and to acquire former Armenian regions in Turkey.' Concluding '... Turkish officials are not unduly alarmed by events in the Caucasus and may even derive some pleasure from seeing the Soviet wrestle with their Armenian problem. ${ }^{11}$,

In light of the war in 2020, Turkey now has a more pro-active approach in NagornoKarabakh, supporting Baku diplomatically, and offering Azerbaijan the possibility of asking for direct military assistance. Turkey announced that it would respond favourably. We are thus witnessing the emergence of a Turkey which is displaying its ambitions on the periphery and does not hesitate to disturb the balance within NATO by opposing France rather than the United States. ${ }^{12}$

\subsection{The Allies Turkey and Azerbaijan}

As illustrated above, the heated tensions between these conflicting parties date back to the Soviet era. The official recognition of the Armenian Genocide by the Supreme Council of the Armenian SSR on 20 November 1988 fuelled new emerging tensions with Turkey that had been kept under control during the Cold War. This partly explains the support of Turkey that the latter gave to Azerbaijan. It also explains the CIA's interest in Nagorno-Karabakh in the 1980s to understand Turkey's diplomatic position in the region.

\footnotetext{
attachment to their homeland. The Armenian American community is the most politically influential community of the Armenian diaspora. The Armenian National Committee of America (ANCA) and Armenian Assembly of America advocate for the recognition of the Armenian Genocide by the American government and support stronger bilateral relations. The Armenian General Benevolent Union (AGBU) is providing financial support and advertising Armenian culture worldwide.

${ }^{11}$ Central Intelligence Agency (CIA), Unrest in the Caucasus and the Challenge of Nationalist, 1988 (declassified in 1999).

12 This situation could not have been foreseen by the CIA in 1988 because Sarkozy announced France's return to NATO's military command in 2009.
} 
In the 1990s, the Turkish government in Ankara took a more pro-active approach and provided economic and military assistance to Baku, as the return of an independent Armenia allowed it to take a position on the conflict without offending Moscow. Turkish intelligence and armed forces crossed the border with 350 officers and volunteers who joined Azerbaijan's armed forces in the fight against post-Soviet Armenia in Nagorno-Karabakh during the 1988-1994 war. ${ }^{13}$ A two-sided conflict emerged with Armenia supported by Russia and Greece against Azerbaijan, supported by Turkey, the Chechens of Itchkeria and the Afghans of Hezb-e-Islami Gulbuddin. ${ }^{14}$

It was assumed then by the US administration that Ankara's diplomatic choice to engage in moderation, even after the collapse of the USSR, is partly due to its ambiguous relations with post-Soviet Russia-also bearing in mind that today all the countries involved are members of the OSCE.

Supporting Azerbaijan would be tantamount to inciting Moscow to increase its military presence in Armenia to counterbalance that of Turkey in Azerbaijan in order to restore a balance of power and preserve the status quo in Nagorno-Karabakh and the South Caucasus in general. Moreover, Russia's military presence in Transnistria (1992) in Moldavia and in Abkhazia and South Ossetia (1992) in Georgia attests to Moscow's ability to carry out military actions to ensure stability in the post-Soviet space. A large-scale conflict in Nagorno-Karabakh could threaten bilateral relations between Moscow and Ankara in the post-Soviet world order.

Although Turkey gave its rhetorical support to Azerbaijan in 2020, thus disrupting relations among NATO member states and at the OSCE, Ankara nonetheless did not object to the announcement of Russia's choice to send peacekeeping troops. In this respect, as described by the CIA in 1988, Turkey is more active diplomatically but is still fearful of Russia, which remains the main military power in the South Caucasus.

\subsection{Role of Kin State: Moscow's Ambiguous Presence in Nagorno-Karabakh}

In the Caucasus, the presence a kin-state like the Russian Federation is exogenous and perceived by the peoples there as a form of interference in regional conflicts. Consequently, forging an alliance with Moscow makes it possible to implement a status quo and prepare for the next conflict, in particular by strengthening the demographic situation in a country. The 1988 CIA paper already highlights this dynamic with the statistics on demography in Nagorno-Karabakh. The latter attests to a decrease in the Russian presence in favour of Azeris and Armenians.

Yet, previous Soviet policies directed at the Caucasus under communist dictator Josef Stalin, he himself Caucasian, from the 1920s till his death in 1953, took into

\footnotetext{
${ }^{13}$ Flanagan Stephen, Brannen Samuel (2018). Turkey's Shifting Dynamics: Implications for U.S.Turkey Relations, United-States, Center for Strategic and International Studies, page 17.

${ }^{14}$ Hunter Shireen (2004). Russia and the Transcaucasus: The Impact of the Islamic Factor. Islam in Russia: The Politics of Identity and Security, M.E. Sharpe, page 349.
} 
account the ethnic, religious and linguistic divisions within the Caucasus peoples to push them against each other and impose Moscow's presence other than by the use of force. ${ }^{15}$ Stalin knew how to play on the oppositions between peoples and stemmed the emergence of a Soviet State on the basis of a single ethnic group, language, or religion, namely Russian and Russian language and Orthodox Christian-although any religion was kept low to be slowly replaced by communist ideology.

Alongside the integration of Abkhazia into the Georgian SSR or Transnistria into the Moldovan SSR, the choice of integrating Karabakh into the Azerbaijan SSR made it possible to stem the emergence of an overly autonomous Armenia and Azerbaijan. During the Soviet period, the fear that Nagorno-Karabakh would lose its autonomous oblast status led the Armenian SSR to accept demands from Moscow. Similarly, the Azerbaijan SSR, fearing the loss of Nagorno-Karabakh, was ready to accept Moscow's demands and move away from Turkey, and Iran with which it shares the same religion of Shiite Islam.

Yet since the mid-1980s, Mikhail Gorbachev's policies challenged the balance of power established by Stalin in the USSR, including in Nagorno-Karabakh. The opening and changing of the Soviet Union under Glasnost and Perestroika led to a dialogue on nationalism and identity, and eventually to a debate on whether NagornoKarabakh should belong to Azerbaijan or Armenia.

The return of the debate on national identity at the end of the 1980s revived ethnic and religious conflicts, leading to violence that Moscow was unable to contain with the local police, the only solution being the permanent presence of a peacekeeping force. Permanent troops stationed in Nagorno-Karabakh would be similar to the USSR's approach in Afghanistan (1979-1989) and would be expensive ${ }^{16}$ and not approved by Soviet citizens. Hence, it was stated in the CIA paper, that "in retrospect, Gorbatchev may have miscalculated the impact of glasnost. His actions and speeches during the past years suggest he may have been unduly optimistic that diverse interests of national groups can be accommodated and reconciled within the framework of the Soviet unitary state. Glasnost has led to an expanded discussion by minorities of legal, economic, and cultural rights, as well as greater public discourse on the past 'wrongs' perpetrated against them. Since the beginning of the year there have been major national demonstrations in nine of the 15 republics and numerous smaller incidents elsewhere." Central Intelligence Agency (CIA), Unrest in the Caucasus and the Challenge of Nationalist, 1988 (declassified in 1999).

In 2020, Russia came back to this decision and sent peacekeepers. For Moscow, this choice is not an easy one, both financially and diplomatically, and announces multiple upheavals on an international scale. To begin with, the government in Moscow will henceforth be responsible for the protection of civilians in NagornoKarabakh on both sides. The withdrawal of Russian troops would lead to a return of hostilities which will target inhabitants on both sides.

\footnotetext{
${ }^{15}$ Madel William (1985). Soviet but not Russian: The other peoples of the Soviet Union. University of Alberta Press.

16 The USSR was already struggling with Chernobyl's nuclear disaster and other economic difficulties after 1986.
} 
Furthermore, the Russian government will once again appear to be a disruptive force in the eyes of the West and in particular the Minsk Group at the OSCE. Russia, the United States and France are co-chairmen of the Minsk Group, and the presence of Russian troops means that the Kremlin is, therefore, the only country able to decide the future of the conflict, giving the Kremlin an undeniable advantage that France and the United States are unlikely to appreciate. Finally, on a financial level, ensuring a permanent military presence comes at a financial cost. Moscow is going to have to invest in a force on the ground, without being able to withdraw it and not gaining any benefit from it as the two countries will continue to hate each other. This is why the USSR was reluctant to send troops to Nagorno-Karabakh during and after the 1988-1994 war.

In the end, the Russian government would notably benefit indirectly from a military presence in a region of the world where it was otherwise absent, but also through the export of arms to the two protagonists. Armenia has all the interest in aligning itself with Moscow's diplomatic position and continuing to purchase Russian equipment in order to win the Kremlin's favour and avoid a withdrawal of peacekeepers. Azerbaijan might have a diplomatic interest in doing the same to obtain Russia's endorsement and request the return of more occupied territories during future negotiations with Moscow.

\subsection{Further Research}

One could argue that the causal link between the frozen conflicts in the 1980s and silencing of the past, and the unresolved ethnic and religious discrepancies, including the Armenian Genocide, will lead to the re-emergence of the conflict over NagornoKarabakh.

Interestingly, back in 1988, the CIA research paper posited the options available to Moscow to alleviate tensions between Yerevan and Baku, namely to first maintain the status quo, which required questioning Gorbachev's policies (glasnost and perestroika), and secondly, to grant economic benefits to the conflicting parties in order to ease tensions, similar to what was done in the Abkhazian SSR.

This strategy did not seem to have been efficient because Armenians and Azeris are fighting for land almost as a proxy for unresolved religious and ethnic issue, making this conflict more complex than in Abkhazia or Transnistria. But to simply increase the autonomy of Nagorno-Karabakh within Azerbaijan, which seems temporary as it does not satisfy anyone in the capital cities of Yerevan, Baku, or Stepanakert in Nagorno-Karabakh.

Hence, it is worth looking back to the prediction in the 1980s to better understand current and ongoing conflicts in the region, its key actors and geopolitics, beyond the 2020 war. 
Numerous solutions have been mentioned, even the possibility of bringing the territory of Nagorno-Karabakh under the direct control of the Russian government. Back in 1988 it was even proposed that the government of Azerbaijan could adopt the "Extraterritorial Native Cultural Institutions," which proposed more autonomy in the linguistic and cultural field for the Armenian minority of Nagorno-Karabakh without changing its level of autonomy within Azerbaijan. The authors of the paper recommended attaching Nagorno-Karabakh to the Armenian Republic. This option was perceived as too "radical" according to the CIA, and difficult because it creates tensions with Azerbaijan. Already in 1988, giving more autonomy to NagornoKarabakh within Azerbaijan would require direct military interference by Moscow and would stir up tensions between Armenians and Azerbaijanis, but to a lesser extent than the transfer of the territory to one of the protagonists. It could only bring temporary stability to Nagorno-Karabakh, but would remain costly and would require going against Gorbachev's policy of glasnost and perestroika in order to put an end to the debate on national identity in Armenia and Azerbaijan.

The developments and the war until 1994 showed that post-Soviet Russia and the Western Allies, let alone members of the OSCE Minsk Group have failed to find a permanent solution satisfying Armenia and Azerbaijan. In 2020 Russia refused to send peacekeeping troops to Nagorno-Karabakh, unlike to the other partially and unrecognised states in the post-Soviet space, namely Transnistria, Abkhazia, South Ossetia, Eastern Ukraine, which are monitored or observed by the OSCE.

The CIA research paper remains relevant to the US Department of State today for understanding the conflict and in particular the complexity of the relationship between Azerbaijan and Turkey, as well as that between Armenia and Russia. Overall, the CIA research paper shows continuity between Soviet and Russian policy in Nagorno-Karabakh, with difficulties in supporting either side, in contrast to Turkey's indirect involvement in the region in the post-Soviet order, which was not the case before the collapse of the USSR.

The contemporary context confirms the CIA's analysis but requires more in-depth research on today's situation and the causes for the ongoing conflict. Some 30 years later, Russia remains an ambiguous exogenous power in the Caucasus. Moscow does not wish to interfere militarily in Nagorno-Karabakh, in contrast to Abkhazia, South Ossetia and Transnistria, because it would push Azerbaijan to turn towards Turkey and the Euro-Atlantic community to recover control over the territory. Nowadays, it is difficult to understand the disputes in the South Caucasus without looking at other regional actors, such as Turkey and Iran.

However, Moscow is not in a position to leave Armenia alone to defend NagornoKarabakh because Yerevan lacks military capabilities compared to Azerbaijan. ${ }^{17}$ This attitude of the Russian government highlights a discrepancy between the rhetoric in the OSCE seeking a compromise between Armenia and Azerbaijan, and Russia's

\footnotetext{
${ }^{17}$ Baku is enjoying some income due to gas and oil industries making it able to modernise its Armed Forces, which is not the case of Armenia. Murad Ismayilov (2014) Power, knowledge, and pipelines: understanding the politics of Azerbaijan's foreign policy, Caucasus Survey, 2:1-2, 79-129, https:// doi.org/10.1080/23761199.2014.11417304
} 
pragmatic attitude in the South Caucasus of not expecting the conflict to end. Russia is not in a position to unilaterally send peacekeepers to Nagorno-Karabakh because it would not satisfy Armenia, Azerbaijan or Nagorno-Karabakh to establish a temporary status quo. The CIA's analysis and the notion of "unrest" mentioned in the title of the research paper remains accurate in 2020.

Russia will have to stay close to Nagorno-Karabakh with its military installation in Armenia to ensure that Azerbaijan and Turkey remain cautious when it comes to military intervention in the region.

For the US Department of State, the recognition of Nagorno-Karabakh by ten American states also shows the relevance of the CIA's analysis to evaluate the influence of the Armenian diaspora in the United States and how it could weaken American diplomacy within NATO and in other international organisations such as the United Nations and the OSCE.

The CIA's analysis was relevant until the outbreak of the conflict in September 2020, and seems to be less relevant since the arrival of Russian troops in NagornoKarabakh on 10 November 2020. Russia has therefore decided to adopt a more pro-active approach in the region in response to the attack on its Mi-24 helicopter by Azerbaijan, and because it will enable it to reaffirm its status as a great power while at the same time reaping economic benefits from the sale of arms to the two protagonists who wish to attract Moscow's favours. Contrary to the Soviet era when Soviet peacekeeping troops would have been expensive, the contemporary context makes Russia an arms supplier, and Azerbaijan and Armenia two potential buyers.

With this strategic choice, Moscow ensures that it will be the main player within the OSCE Minsk Group, since France and the United States do not have troops on the ground and are not in a position to determine directly whether or not hostilities will resume, unlike Russia.

American diplomacy seems to remain similar to that of 1988, with an Armenian diaspora influencing US national policy with more than ten states that have recognised Nagorno-Karabakh. The 2020 conflict occurred during the American election period, with Republicans and Democrats preferring to keep their attention on other issues, making it difficult to know to what extent Washington would have reacted outside of the election period.

The main opposition that emerged in 2020 was not between Washington and Ankara but between France and Turkey, two NATO and OSCE member countries. This situation could not have been foreseen by the CIA in 1988, because Sarkozy announced France's return to NATO's military command in 2009.

The CIA's analysis and the report "Unrest in the Caucasus and the Challenge of Nationalist" were relevant before September 2020, which seems to be only partially the case today as Russia has reversed its decision not to send peacekeeping troops. 


\section{References}

Central Intelligence Agency (1949) Who's Who - Political, Military (declassified in 2011) https:// www.cia.gov/library/readingroom/document/cia-rdp80-00809a000600210518-4

Central Intelligence Agency (1952) Indication of Psychological Vulnerabilities (declassified in 2003) https://www.cia.gov/library/readingroom/document/cia-rdp80-00809a000500740051-1

Central Intelligence Agency (1988) Unrest in the Caucasus and the Challenge of Nationalist (declassified in 1999) https://www.cia.gov/readingroom/docs/CIA-RDP91B00776R000600150001-9. pdf

Flanagan S, Brannen S (2008) Turkey's shifting dynamics: implications for U.S.-Turkey relations. United-States, Center for Strategic and International Studies

Hedenskog J, Holmquist E, Norberg J (2018) Security in the Caucasus: Russian policy and military posture. Försvarsdepartementet

Hunter S (2004) Russia and the transcaucasus: the impact of the Islamic factor, Islam in Russia: the politics of identity and security. M.E. Sharpe

Kasapoglu C (2017) Russian forward military basing in Armenia and Moscow's influence in the South Caucasus. Research Paper No. 143, Nato Defense College

Labarre F, Niculescu G (2017) Harnessing regional stability in the South Caucasus: the role and prospects of defence institution building in the current strategic context. Bundesheer Band $10 / 2017$

Mandel W (1985) Soviet but not Russian. University of Alberta Press

Murad I (2014) Power, knowledge, and pipelines: understanding the politics of Azerbaijan's foreign policy. Caucasus Survey 2(1-2):79-129. https://doi.org/10.1080/23761199.2014.11417304

Service de Presse de l'Otan, Déclaration du conseil de l'Atlantique Nord concernant la crise centrée sur le Haut-Karabakh (1992) https://archives.nato.int/uploads/r/null/1/4/142002/PRESS_ RELEASE_92_48_FRE.pdf

Webster W (1988) History of Armenian-Azeri Animosity, Central Intelligence Agency (declassified in 2012) https://www.cia.gov/library/readingroom/document/cia-rdp90g01353r001500220 $005-1$

Open Access This chapter is licensed under the terms of the Creative Commons Attribution 4.0 International License (http://creativecommons.org/licenses/by/4.0/), which permits use, sharing, adaptation, distribution and reproduction in any medium or format, as long as you give appropriate credit to the original author(s) and the source, provide a link to the Creative Commons license and indicate if changes were made.

The images or other third party material in this chapter are included in the chapter's Creative Commons license, unless indicated otherwise in a credit line to the material. If material is not included in the chapter's Creative Commons license and your intended use is not permitted by statutory regulation or exceeds the permitted use, you will need to obtain permission directly from the copyright holder.

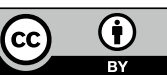

